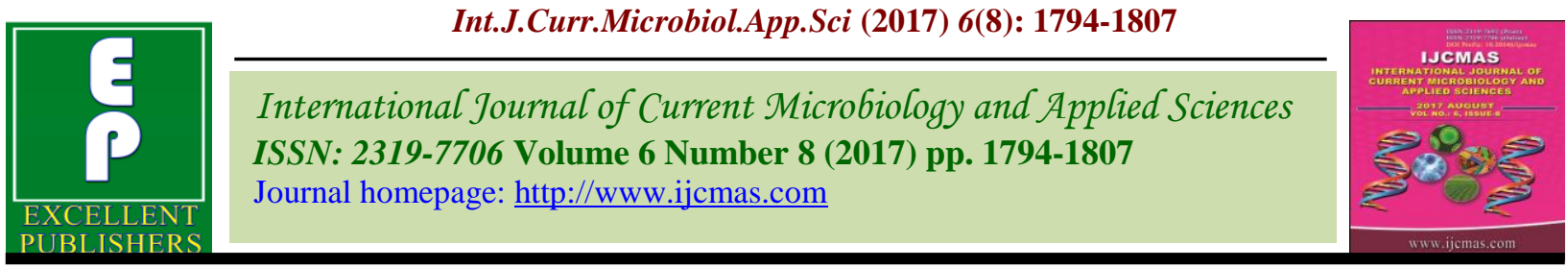

Review Article

https://doi.org/10.20546/ijcmas.2017.608.212

\title{
Influence of FYM, Brown Manuring and Nitrogen Levels on Direct Seeded and Transplanted Rice (Oryza sativa L.): A Review
}

\author{
Ashu Sharma*, Neetu Sharma, Anil Kumar, B.C. Sharma, \\ Lobzang Stanzen, Amit Mahajan and Sapna Bhagat
}

\author{
Division of Agronomy, FOA, Main Campus, SKUAST-J, Chatha \\ *Corresponding author
}

\section{A B S T R A C T}

\section{Keywords \\ FYM, Inorganic fertilizers, Nitrogen levels, Brown manuring, Direct seeded rice, Transplanted rice. \\ Article Info \\ Accepted: \\ 19 June 2017 \\ Available Online: \\ 10 August 2017}

The application of farmyard manure (FYM) in conjunction with inorganic fertilizers significantly increased yield attributes and yield of rice. Application of FYM improved available nutrients, porosity, organic carbon, cation exchange capacity (CEC), and aggregation of soil and reduced bulk density. Inorganic fertilizers in conjunction with FYM improved quality parameters of rice. Grain yield of direct seeded rice with brown manuring Sesbania was statistically at par with conventional transplanting of rice. Rice grain yield increased with increase in dose of nitrogen to a certain level and after that increase in nitrogen level was uneconomical. Maximum nutrients uptake recorded with higher level of nitrogen. Direct seeded rice gave higher water-use efficiency, maintained good physical conditions and provided chance for timely sowing of succeeding wheat crop. Similar quality parameters of rice (hulled, milled and head rice recovery) were recorded with different establishment methods.

\section{Introduction}

Rice (Oryza sativa L.) is the principal source of food for more than half of the world population, especially in South and Southeast Asia and Latin America. It is the main staple food crop of India, covering an area of about $39.16 \mathrm{~m}$ ha with total production of $85.59 \mathrm{mg}$ of rice during 2012-2013 (Anonymous, 2014). Rice is cultivated mainly through transplanting in puddled field, which results in formation of a hard pan and damages soil structure, though it helps in retention of more water and effective in weed control, but this needs more time, labour, energy. Puddling delays planting of succeeding wheat crop and reduces wheat root growth and this limits water uptake and consequently lower the crop yield. Moreover, this technique requires continuous ponding of water for establishment of the seedlings in general and for full effectiveness of applied herbicides, in particular. This in turn leads to nutrient losses through leaching besides causing high evapotranspiration (ET) losses during the hot summer months. In addition, it has been realized that at cultivar's fields plant population varies from 16-21 hills $\mathrm{m}^{-2}$ as against the recommended 33 hills $/ \mathrm{m} 2$, which acts as a yield limiting factor. Presently, the farmers transplant paddy in the first week of June when the daily evaporation rate is very 
high (8-10 mm day $\left.{ }^{-1}\right)$. Moreover, in the IndoGangetic Plains (IGP) the underground water is being over exploited by excessive pumping to meet the water need of transplanted paddy. As a consequence, it has been causing a sharp decline in ground water table. Therefore, of late, need has acutely been felt to develop technically viable and economically feasible alternate technique for growing paddy in this area. The preliminary research conducted at Punjab Agricultural University indicated that direct seeded rice could be a viable alternative to transplanted rice due to availability of short duration varieties, effective herbicides, nonavailability of labour and escalating cost of labour. It is now fast replacing traditional transplanted rice in areas with good drainage and weed control (Balasubramanian and Hill, 2002). Further, it also shortens the cropping cycle due to absence of transplanted shock to the seedlings. Direct seeding cultivation therefore, could also help to ensure the timely sowing in a stipulated time. Fertilizers have contributed substantially to the spectacular increase in crop production. However, application of inorganic fertilizers alone in large quantities over a longer period of time results in imbalance in the supply of other nutrients. The combined use of organic manures and inorganic fertilizers help in maintaining yield stability through correction of marginal deficiencies of secondary and micronutrients, enhancing efficiency of applied nutrients and providing favourable soil physical conditions. Application of farm yard manure (FYM) to soil improves the physical, chemical and biological properties thereby improving the nutrient availability in soils. Fertilizer N-use efficiency varies from $18-40 \%$ in rice soils, because applied inorganic $\mathrm{N}$ is rapidly lost from the soil by ammonia volatilization and denitrification. Urea is the principal nitrogenous fertilizer in rice-growing Asian countries. Large loss of $\mathrm{N}$ from urea necessitates an innovative application technique for increasing the $\mathrm{N}$-use efficiency. Application of urea in combination with organic material (FYM) minimizes $\mathrm{N}$ loss and increasing $\mathrm{N}$-use efficiency.

Brown manuring is a practice of seeding Sesbania with rice and applying 2, 4-D @ 400-500 $\mathrm{g} \mathrm{ha}^{-1}$ to knockdown the Sesbania at 30 days after seeding. This practice results into falling of Sesbania leaves on the ground and forms a mulch and helps in smothering of weeds, conserving moisture and adding about $15 \mathrm{~kg} \mathrm{~N} \mathrm{ha-1} \mathrm{without} \mathrm{adding} \mathrm{much} \mathrm{on} \mathrm{cost} \mathrm{of}$ production (only seed cost).

\section{Influence of $\mathrm{FYM}$ on rice}

\section{Yield attributes}

The application of FYM @ $10 \mathrm{t} \mathrm{ha}^{-1}$ in conjunction with different fertilizer levels exhibited a significant increase in effective tillers per $m$ row length, grain and straw yield of rice over fertilizer treatment alone (Azad and Lehria, 2001). However, Kumar et al., (2003) reported that FYM @ $20 \mathrm{t} \mathrm{ha}^{-1}$ resulted in significantly higher values of yield attributes (panicle length, filled spikelets panicle $^{-1}$ and 1000-grain weight) and grain yield of rice over control and wheat straw applied@5 or $10 \mathrm{t} \mathrm{ha}^{-1}$ as well as $50 \% \mathrm{~N}$ used alone. Mondal et al., (2003) also observed that the number of panicle $/ \mathrm{m}^{2}$ and number of filled grains panicle ${ }^{-1}$ was highest (422.7 and 98.3, respectively) with $75 \%$ of the recommended dose of NPK $(60 \mathrm{~kg} \mathrm{~N}+30$ kg $\mathrm{P}_{2} \mathrm{O}_{5}+30 \mathrm{~kg} \mathrm{~K}_{2} \mathrm{O}$ ) along with FYM @ $4 \mathrm{t}$ $\mathrm{ha}^{-1}$. The maximum rice grain yield $\left(6 \mathrm{t} \mathrm{ha}^{-1}\right)$ was also recorded at $75 \%$ of the recommended dose of NPK+FYM @ $4 \mathrm{tha}$ ${ }^{1}$.Sujathamma and Reddy (2004) revealed that plant height, tillers, leaf area index and dry matter production of rice were significantly higher with the application of $100 \%$ fertilizer N, which was however, comparable with $25 \%$ FYM (N)+75\% fertilizer $\mathrm{N}$ in respect of tiller production during later stages and dry matter 
production during early stages. They also recorded that the application of $100 \% \mathrm{~N}$ through fertilizer produced the highest number of panicle $\mathrm{m}^{-2}$, panicle length and number of total and filled grains/panicle, grain and straw yield of rice as well as $\mathrm{N}$ uptake, which were however, comparable with $25 \%$ FYM $(\mathrm{N})+75 \% \mathrm{~N}$, in respect of grain yield.

\section{Yield}

Singh et al., (2000a) found that rice yield obtained with recommended NPK was statistically at par with that of $50 \%$ of recommended NPK along with $50 \%$ N through FYM and $75 \%$ of recommended NPK. Bharambe and Tomar (2004) indicated that combined application of $100 \%$ recommended dose of NPK fertilizers (100:60:40 kg NPK ha ${ }^{-1}$ ) with FYM @ 8 t ha ${ }^{1}$ found significantly superior in increasing the grain and straw yields of rice (variety Mahamaya). They also indicated that the productivity of rice and wheat was significantly increased with the application of inorganic fertilizers with FYM $\left(8 \mathrm{t} \mathrm{ha}^{-1}\right)$. Chitale et al., (2004) found that highest grain yield of rice $\left(60.5 \mathrm{q} \mathrm{ha}^{-1}\right)$ was obtained with the treatments in which $50 \%$ of $\mathrm{N}$ was substituted through green manure in kharif followed by grain yield of $56.8 \mathrm{q} \mathrm{ha}^{-1}$ in which $50 \% \mathrm{~N}$ substitution through FYM which was statistically at par to that of $100 \%$ NPK application (58.1 q ha ${ }^{-1}$ ). The results showed a possibility of saving $50 \%$ fertilizer $\mathrm{N}$ in rice. Parihar (2004) indicated that $100 \%$ NPK recommended along with FYM @ $5 \mathrm{t}$ $\mathrm{ha}^{-1}$ gave highest yield followed by $100 \%$ NPK+wheat straw @ $5 \mathrm{t} \mathrm{ha}^{-1}$. Similarly, the application of $12 \mathrm{t}$ FYM per ha in combination with $80 \mathrm{~kg} \mathrm{~N} \mathrm{ha}^{-1}$ produced the same rice yields $\left(5.7 \mathrm{t} \mathrm{ha}^{-1}\right)$ as that obtained from $120 \mathrm{~kg} \mathrm{~N} \mathrm{ha}^{-1}$ (5.6 t ha ${ }^{-1}$ ) (Gupta et al., 2006). Parasuraman and Mani (2002) observed that with the application of FYM @ $12.5 \mathrm{t} \mathrm{ha}^{-1}$ along with recommended inorganic fertilizers $\left(120 \quad \mathrm{~kg} \quad \mathrm{~N} \quad \mathrm{ha}^{-1}\right)$ produced significantly higher rice grain yield over inorganic fertilizers alone. Roul and Sarawgi (2005) revealed that grain and straw yield were significantly higher under $100 \%$ recommended dose of $\mathrm{N}$ (RDN) blended with FYM and 100 per cent RDN+5 tonnes of FYM than other treatments on pooled data basis (Table 1).

\section{Soil properties}

\section{Physical properties}

The incorporation of wheat straw along with application of FYM reduced the bulk density of soil and increased the porosity of the soil Bhagat and Verma (1991). Mishra and Sharma (1997) observed that application of FYM @ $10 \mathrm{t} \mathrm{ha}^{-1}$ before rice transplanting significantly reduced bulk density $(1.41 \mathrm{mg}$ $\left.\mathrm{m}^{-3}\right)$ than no manure application $\left(1.52 \mathrm{mg} \mathrm{m}^{-}\right.$ $\left.{ }^{3}\right)$. The decrease in bulk density has been ascribed to better organic carbon content and improved soil aggregation. Tiwari et al., (2000) recorded the lowest bulk density (1.20

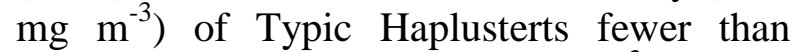
$100 \% \mathrm{NPK}+\mathrm{FYM}$ and $1.49 \mathrm{mg} \mathrm{m}^{-3}$ in plots receiving $\mathrm{N}$ alone or no fertilizers.

\section{Chemical properties}

(Maskina et al., 1988) reported that the use of FYM improved the general soil productivity by increasing soil organic carbon and available nutrients. Sharma and Mittra (1990) also reported marked improvement in organic carbon and available $\mathrm{N}, \mathrm{P}$ and $\mathrm{K}$ in FYM amended plots in rice-wheat rotation. The combined application of FYM and chemical fertilizers to soil in rice-wheat rotation increased the available $\mathrm{N}, \mathrm{P}$ and $\mathrm{K}$ status of soil and also improved its organic carbon content (Brar et al., 1995). Similarly, (Dhiman et al., 1999) reported that organic carbon; available $\mathrm{P}$ and $\mathrm{K}$ were highest where 
an additional FYM application was made. The application of FYM with inorganic fertilizers was more effective as compared to inorganic fertilizers alone in building up soil fertility status (Bajpai et al., 2002). Bharambe and Tomar (2004) indicated that combined application of FYM and inorganic fertilizers was more effective as compared to inorganic fertilizers alone in building up fertility status of soil and increasing the productivity of rice.

\section{Quality parameters}

Rao et al., (1993) indicated that higher levels of $\mathrm{N}\left(60,90 \mathrm{~kg} \mathrm{ha}^{-1}\right)$ decreased the head rice recovery by 3 to 8 per cent and increased amylase content of long slender grain varieties by 3.0 to $9.9 \%$ but not of short slender grain varieties. Dixit and Gupta (2000) reported that quality parameters like hulling percentage, milling percentage, protein and amylase content increased due to use of FYM and NPK fertilizers. Highest carbohydrate $\left(84.9 \mathrm{q} \mathrm{ha}^{-1}\right)$ and protein $(7.72 \mathrm{q}$ $\mathrm{ha}^{-1}$ ) yield of the rice-rice system was obtained when $50 \% \quad \mathrm{~N}$ was substituted through FYM (Raju and Reddy, 2000). Rao et al., (2006) reported that the conjunctive use of $25 \% \mathrm{~N}$ through FYM over and above 100\% recommended dose of $\mathrm{N}$ through fertilizer and $60 \mathrm{~kg} \mathrm{ZnSO} 4 \mathrm{ha}^{-1}$ resulted in best quality parameters viz., Protein, amylase content and head rice recovery which can be attributed to uninterrupted availability of $\mathrm{N}$ coupled with increased absorption and assimilation by plants (Rao et al., 2006). (Mishra et al., 2006) reported that the milling percentage, kernel breadth before and after cooking were significantly higher due to application of organic sources where Sesbania green manuring coupled with FYM @ $10 \mathrm{t} \mathrm{ha}^{-1}$ proved significantly superior.

\section{Influence of brown manuring}

Aslam et al., (2008) found that paddy yield in bed transplanting (4.43 $\left.\mathrm{t} \mathrm{ha}^{-1}\right)$ and direct seeding+brown manuring $\left(4.23 \mathrm{tha}^{-1}\right)$ were at par and significantly higher than direct seeding without brown manuring $\left(3.36 \mathrm{t} \mathrm{ha}^{-1}\right)$ that produced the lower yield (Table 2). Sharma et al., (2008) found that direct seeding with Sesbania co-culture as a brown manuring yielded $\left(3.65 \mathrm{t} \mathrm{ha}^{-1}\right)$ at par, compared to conventional transplanting (3.69 $\mathrm{t} \mathrm{ha}^{-1}$ ) and significantly higher than direct seeding without brown manuring $\left(3.24 \mathrm{t} \mathrm{ha}^{-1}\right)$ and also it saved $43.6 \%$ water over conventional transplanting (Table 3). In integrated weed-management practices, butachlor@1.5 kg ha ${ }^{-1}$ as pre-plant surface application+brown manuring with Sesbania rostrata+2,4-D @0.50 kg ha ${ }^{-1}$ recorded the highest grain yield $\left(3.88 \mathrm{t} \mathrm{ha}^{-1}\right)$, which was significantly on a par with that obtained from season-long weed-free situation $\left(3.98 \mathrm{t} \mathrm{ha}^{-1}\right)$. The highest net returns $\left({ }^{-19,029} \mathrm{ha}^{-1}\right)$ and benefit: cost ratio (1.19) was also recorded in same treatment (Kumar and Mukherjee, 2008). Singh et al., (2009) recorded that rice yield in direct seeding+brown manuring (3.50 $\mathrm{t} \mathrm{ha}^{-1}$ ) were at par, compared to conventional transplanting $\left(3.56 \mathrm{t} \mathrm{ha}^{-1}\right)$ but, significantly higher than direct seeding without brown manuring $\left(3.22 \mathrm{tha}^{-1}\right)$ and also it saved $39.4 \%$ water over transplanting.

At Haryana, Singh et al., (2008b) conducted an experiment and results revealed that Sesbania sown along with rice gave maximum yield $\left(5.54 \mathrm{t} \mathrm{ha}^{-1}\right)$ and it was on par with Sesbania sown at 5 days of rice $(5.41 \mathrm{t}$ $\mathrm{ha}^{-1}$ ) and significantly higher than sole crop of rice $\left(4.70 \mathrm{t} \mathrm{ha}^{-1}\right)$. They also revealed that maximum weed density was observed in sole crop of rice (68 weeds $\mathrm{m}^{-2}$ ) as compared to only $\left(15\right.$ weeds $\left.\mathrm{m}^{-2}\right)$ in Sebania sown along with rice. Singh et al., (2008c) found that direct seeding with Sesbania co-culture as a brown manuring yielded $\left(4.51 \quad \mathrm{t} \quad \mathrm{ha}^{-1}\right)$ significantly at par with conventional transplanting $\left(4.70 \mathrm{t} \mathrm{ha}^{-1}\right)$ and significantly higher than direct seeding without brown manuring $\left(4.00 \mathrm{t} \mathrm{ha}^{-1}\right)$. They also found that 
maximum weed density was observed in direct seeding without brown manuring (40 weeds $\mathrm{m}^{-2}$ ) whereas, direct seeding with brown manuring (15 weeds $\left.\mathrm{m}^{-2}\right)$ and conventional transplanting (16 weeds $\mathrm{m}^{-2}$ ) gave at par weed density.

\section{Influence of levels of nitrogen on yield attributes and yields of rice}

Lawal and Lawal (2002) reported that application of fertilizer up to $80 \mathrm{~kg} \mathrm{~N}$ ha significantly increased crop growth rate, number of ear bearing tillers $\mathrm{m}^{-2}$, and per cent filled grains of rice. While, plant height, test weight (1000-grains weight) and grain weight panicle $^{-1}$ responded to fertilizer up to $120 \mathrm{~kg}$ $\mathrm{N} \mathrm{ha}^{-1}$. The maximum grain yield of rice was obtained with $120 \mathrm{~kg} \mathrm{~N} \mathrm{ha}^{-1}$ which was significantly higher than those obtained with $80 \mathrm{~kg} \mathrm{~N} \mathrm{ha}^{-1}$ and control. Prasad et al., (2003) found that all yield attributing characters increased significantly with the increase in levels of nitrogen from 40 to $100 \mathrm{~kg} \mathrm{ha}^{-1}$. Whereas, an application of $200 \mathrm{~kg} \mathrm{~N} \mathrm{ha}^{-1}$ significantly increased the plant height (127.3 $\mathrm{cm})$, total number of tillers hill ${ }^{-1}$ (16.3), dry matter production $\left(16.0 \mathrm{t} \mathrm{ha}^{-1}\right)$, grain and straw yields $\left(6.5\right.$ and $\left.9.5 \mathrm{t} \mathrm{ha}^{-1}\right)$ of hybrid rice. While $100 \mathrm{~kg} \mathrm{~N} \mathrm{ha}^{-1}$ resulted in highest benefit: cost ratio of crop (Meena et al., 2003). Similarly, Singh et al., (2007) recorded that tiller density and panicle length increased significantly with $\mathrm{N}$ application up to $120 \mathrm{~kg}$ $\mathrm{N} \mathrm{ha}^{-1}$.

\section{Yield}

Singh and Sharma (2000) observed a significant increase in grain and straw yields of rice when the rate of $\mathrm{N}$ application was increased from 0 to $120 \mathrm{~kg} \mathrm{~N} \mathrm{ha}^{-1}$. Further increase in $\mathrm{N}$ application from 120 to $180 \mathrm{~kg}$ $\mathrm{N} \mathrm{ha}{ }^{-1}$ had no significant effect on grain and straw yields of rice. Similarly, Jaiswal and Singh (2001) reported that application of 120 $\mathrm{kg} \mathrm{N}$ ha $^{-1}$ significantly increased the grain yield of rice by 29.7 and 23.7 percent over 60 $\mathrm{kg} \mathrm{N} \mathrm{ha}{ }^{-1}$. It was due to the higher values of yield attributes, which resulted with the higher level of nitrogen. Gill and Walia (2014) revealed that significantly higher grain and straw yield of basmati rice was obtained with $125 \%$ of recommended dose of nitrogen (90 kg urea ha ${ }^{-1}$ ) over control, 75 and 100\% of recommended dose of nitrogen. Similarly, grain yield of wet-direct seeded rice increased significantly with the application of fertilizer $\mathrm{N}$ as compared to no $\mathrm{N}$ control. The $\mathrm{N}$ response of wet direct seeded rice was observed up to $120 \mathrm{~kg} \mathrm{~N}^{-1}$ where applied $\mathrm{N}$ fertilizer increased grain yield by $62 \%$ compared to control. Beyond $120 \mathrm{~kg} \mathrm{~N} \mathrm{ha}^{-1}$, no increase in grain yield was observed but its application resulted in more production of rice straw (Singh et al., 2007). However, Khan et al., (2006) recorded significant increase in the rice grain yield occurred up to $180 \mathrm{~kg} \mathrm{~N} \mathrm{ha}^{-1}$. Above $180 \mathrm{~kg} \mathrm{~N} \mathrm{ha}^{-1}$ the rice grain and straw yield declined because of crop lodging and delayed maturity at higher $\mathrm{N}$ dose i.e., $240 \mathrm{~kg} \mathrm{~N} \mathrm{ha}^{-1}$. The beneficial effect of $\mathrm{N}$ can be explained in the light of the fact that it increased the number of panicles $/ \mathrm{m}^{2}$ and number of grains per panicle that ultimately contributed to higher grain yield.

\section{Nutrient-uptake of rice}

Nitrogen at $120 \mathrm{~kg} \mathrm{~N} \mathrm{ha}{ }^{-1}$ increased the nitrogen uptake by 41.9 and $34.8 \%$ over $60 \mathrm{~kg}$ $\mathrm{N} \mathrm{ha}^{-1}$ in grain and straw, respectively. Higher uptake of $\mathrm{N}$ might be due to better established roots, better plant growth and yield under increased N level (Jaiswal and Singh, 2001). Similarly, total $\mathrm{N}$ uptake by rice increased significantly with the increasing $\mathrm{N}$ rates up to $160 \mathrm{~kg} \mathrm{~N} \mathrm{ha}{ }^{-1}$. However, the recovery, agronomic and physiological efficiencies of applied $\mathrm{N}$ were highest in the $120 \mathrm{~kg} \mathrm{~N}^{-1}$ treatment (Singh et al., 2007). Laroo et al., (2007) revealed that $\mathrm{N}$ uptake was significantly influenced due to different levels of $\mathrm{N}$ application. Based on the total $\mathrm{N}$ uptake 
(grain+straw), there was 49.9, 63.9 and $70.4 \%$ increase in $\mathrm{N}$ uptake over the control with 50 , 100 and $150 \mathrm{~kg} \mathrm{~N} \mathrm{ha}^{-1}$,respectively.

\section{Influence of methods of sowing on yield attributes and yields of rice}

\section{Yield attributes}

Dhiman et al., (1999) reported that nonscented varieties performed better under transplanted condition due to more number of grains per panicle and panicle weight as compared to direct seeded rice in clay loam soil. However, Zhang and Zhu (1999) reported that no-tillage direct sown rice gave greater plant height and number of effective tillers than transplanted rice. Samra and Dhillon (2000) reported that rice transplanted after puddling gave significantly higher yield over puddled broadcast sprouted seeds and line sowing of sprouted seeds without puddling due to no lodging and more number of panicles $\mathrm{m}^{-2}$, test weight and grain weight panicle $^{-1}$ in loamy sand soil. Jaiswal and Singh (2001) while working at Faizabad obtained significantly higher yield of transplanted rice than direct broadcasting of pre-germinated seeds in loam soil due to significantly higher number of panicles $\mathrm{m}^{-2}$, grains per panicle and panicle length. Similar results were reported by Singh et al., (1990) and Singh et al., (1997).

\section{Yield}

Budhar and Tamilselvan (2002) revealed that wet seeding of rice by manual broadcasting $\left(57.2 \mathrm{q} \mathrm{ha}^{-1}\right)$ and wet seeding by drum seeder (56.6 $\mathrm{q} \mathrm{ha}^{-1}$ ) has recorded higher yield and it was statistically at par with the traditional transplanting method (55.8 $\left.\mathrm{q} \mathrm{ha}^{-1}\right)$. In another studies, Singh et al., (2005b) found that crop established by conventional method resulting in higher grain yield (49.2 $\mathrm{q} \mathrm{ha}^{-1}$ ) followed by broadcasting of sprouted seeds (45.7 $\left.\mathrm{q} \mathrm{ha}^{-1}\right)$, which was significantly higher over dry seeding (40.8 $\left.\mathrm{q} \mathrm{ha}^{-1}\right)$. Transplanting method and broadcasting of sprouted seeds increased the grain yield of rice by 17.2 and $10.8 \%$, respectively over dry seeding due to better growth and development. However, Singh et al., (2005a) studied the influence of crop establishment methods on rice and found that puddling followed by transplanting of rice (77.2 $\mathrm{q} \mathrm{ha}^{-1}$ ), puddling and broadcasting of sprouted seed (75.8 $\left.\mathrm{q} \mathrm{ha}^{-1}\right)$ and zero tillage transplanting $\left(73.9 \mathrm{q} \mathrm{ha}^{-1}\right)$ gave the comparable yield. Gill et al., (2006a) studied the performance of various methods of rice seeding and revealed that maximum grain yield (48.3 $\mathrm{qha}^{-1}$ ) was recorded in direct seeding which was significantly more than the transplanting (43.8 $\mathrm{q} \mathrm{ha}^{-1}$ ) with a margin of $5.5 \mathrm{q} \mathrm{ha}^{-1}$. However, Gill et al., (2006b) concluded that maximum grain yield $(68.6 \mathrm{q}$ $\mathrm{ha}^{-1}$ ) was recorded with transplanting method, which was however at par with wet direct seeding (64.6 q ha-1) (Table 4).

Sanjay et al., (2006a) enumerated that grain yield of rice was significantly influenced by planting systems. Line transplanting system recorded significantly higher grain yield (55.3 $\mathrm{q} \mathrm{ha}{ }^{-1}$ ) as compared to direct seeding using drum seeder (54.3 q ha $\mathrm{qa}^{-1}$ ) and broadcast sowing (30.5 $\left.\mathrm{q} \mathrm{ha}^{-1}\right)$ whereas, direct seeding using drum seeder recorded significantly higher straw yield (73.7 $\left.\mathrm{q} \mathrm{ha}^{-1}\right)$ compared to line transplanting $\left(69.9 \mathrm{q} \mathrm{ha}^{-1}\right)$ and broadcast sowing (55.4 q ha-1). However the direct seeding using drum seeded recorded significantly higher grain (61.7 $\left.\mathrm{q} \mathrm{ha}^{-1}\right)$ and straw yield (112.7 $\mathrm{q} \mathrm{ha}^{-1}$ ) as compared to line transplanting grain yield of $57.1 \mathrm{q} \mathrm{ha}^{-1}$ and straw yield of $105.3 \mathrm{q} \mathrm{ha}^{-1}$ (Sanjay et al., 2006b). Gill and walia (2014) reported that basmati rice grain yield was significantly higher with machine transplanting after puddling than conventional transplanting of basmati rice but was statistically at par with direct seeded basmati rice with brown manuring. 


\section{Maturity}

The direct seeded tropical low land rice sown by broadcast method in puddled seed bed produced more tillers, vegetative growth and shorten the crop duration by more than one week and 10-12 days earlier maturity (Nagappa et al., 2002). Budhar et al., (1990) reported increased number of panicles and early maturity in rice under direct seeding compared to transplanting of rice in case of short duration cultivar. Broadcasting of sprouted seeds and drum seeding methods had 7.2 and 6.9 days earlier flowering than transplanted crop (Santhi et al., 1998). Budhar and Tamilselvan (2002) reported that the direct seeding by manual broadcasting and drum seeder reduced the time in $50 \%$ flowering by 7 days compared with transplanting and throwing of seedlings on red sandy loam soils.

\section{Water requirement of rice}

Direct sowing with sprouted seeds on puddled soil gave an equal yield with transplanted rice but the water-use efficiency was higher with partial submergence at Delhi on sandy clay loam soil (Hukkeri and Sharma, 1980). Narayansamy et al., (1993) also reported from Thanjavur in Tamil Nadu that in direct sown rice under puddle conditions, the crop used less water (878-894 $\mathrm{mm}$ ) than in transplanted rice $(1153-1177 \mathrm{~mm}$ ) and had the highest water-use efficiency in clay loam soil. Thabonithy and Murali (1994) reported that dry seed broadcasted on unpuddled soil was the best method of rice establishment on heavy clay soils with the total water requirement of $1040 \mathrm{~mm}$ in comparison to $1154 \mathrm{~mm}$ of transplanted rice. However, Goel and Verma (2000) observed that the average water-use efficiency was $10.7 \%$ more in transplanting method. Tabbal et al., (2002) reported that direct wet seeded rice yielded higher than traditional transplanting by 3$17 \%$, required $19 \%$ less water during crop growth period and increased water productivity by $25-48 \%$ with continuous standing water conditions. They also found that under water saving irrigation i.e. keeping the soil continuously around saturation, wet seeded rice out yielded transplanted rice by $6-$ $36 \%$ and were a suitable establishment method to save water and retain high yields at Philippines (Table 4).

Table.1 Effect of different stand establishment techniques on rice yields and its attributes

\begin{tabular}{|l|l|l|l|l|l|l|}
\hline Treatments & $\begin{array}{l}\text { Plant } \\
\text { height } \\
(\mathrm{cm})\end{array}$ & $\begin{array}{l}\text { Productive } \\
\text { Tillers } \mathrm{m}^{-2}\end{array}$ & $\begin{array}{l}\text { Panicle } \\
\text { length } \\
(\mathrm{cm})\end{array}$ & $\begin{array}{l}\text { Number of } \\
\text { grains } \\
\text { panicle }\end{array}$ & $\begin{array}{l}\text { 1000-grain } \\
\text { weight } \\
(\mathrm{g})\end{array}$ & $\begin{array}{l}\text { Paddy } \\
\text { yield } \\
\left(\mathrm{t} \mathrm{ha}^{-1}\right)\end{array}$ \\
\hline $\begin{array}{l}\text { Double zero } \\
\text { tillage }\end{array}$ & 136.1 & 219.0 & 27.93 & 96.50 & 23.17 & 4.80 \\
\hline $\begin{array}{l}\text { Direct } \\
\text { seeding }\end{array}$ & 126.1 & 231.7 & 25.23 & 72.67 & 22.17 & 3.36 \\
\hline $\begin{array}{l}\text { Brown } \\
\text { manuring }\end{array}$ & 128.2 & 186.3 & 27.67 & 93.83 & 22.83 & 4.23 \\
\hline Bed planting & 129.2 & 206.7 & 27.93 & 95.73 & 23.17 & 4.43 \\
\hline $\begin{array}{l}\text { Conventional } \\
\text { planting }\end{array}$ & 130.2 & 200.2 & 27.93 & 98.57 & 23.50 & 4.72 \\
\hline LSD $(p=005)$ & 2.782 & 26.65 & 0.9019 & 8.851 & 0.9676 & 0.2844 \\
\hline Source: Aslam et al., 2008 &
\end{tabular}


Table.2 Effect of different crop establishment techniques on yield and water productivity of basmati rice

\begin{tabular}{|c|c|c|c|c|c|c|}
\hline $\begin{array}{l}\text { Crop establishment } \\
\text { technique }\end{array}$ & $\begin{array}{l}\text { Grain } \\
\text { Yield } \\
\left(\mathrm{t} \mathrm{ha}^{-1}\right) \\
\end{array}$ & $\begin{array}{l}\text { Water } \\
\text { applied } \\
\left(\mathrm{m}^{2}\right)\end{array}$ & $\begin{array}{l}\text { Irrigated water } \\
\text { productivity } \\
\left(\mathrm{kg} \mathrm{m}^{-3}\right)\end{array}$ & $\begin{array}{l}\text { Rainfall } \\
(\mathrm{mm})\end{array}$ & $\begin{array}{l}\text { Gross water } \\
\text { productivity } \\
\left(\mathrm{kg} \mathrm{m}^{-3}\right)\end{array}$ & \begin{tabular}{|l} 
Water \\
saving \\
$(\%)$
\end{tabular} \\
\hline Conventional tillage & 3.69 & 1.26 & 0.29 & 0.20 & 0.25 & - \\
\hline $\begin{array}{l}\text { Unpuddled } \\
\text { transplanting }\end{array}$ & 4.00 & 1.25 & 0.32 & 0.20 & 0.27 & - \\
\hline $\begin{array}{ll}\text { Raised } & \text { bed } \\
\text { transplanting } & \end{array}$ & 2.95 & 0.95 & 0.31 & 0.20 & 0.26 & 24.60 \\
\hline Direct seeded rice & 3.24 & 0.76 & 0.42 & 0.23 & 0.32 & 39.68 \\
\hline $\begin{array}{l}\text { Direct seeded } \\
\text { rice+Sesbania }\end{array}$ & 3.65 & 0.71 & 0.51 & 0.23 & 0.38 & 43.65 \\
\hline $\begin{array}{ll}\text { Direct } & \text { seeded rice } \\
\text { at } & \text { transplanting } \\
\text { time } & \\
\end{array}$ & 2.91 & 0.64 & 0.46 & 0.23 & 0.43 & 49.20 \\
\hline $\operatorname{LSD}(p=005)$ & 0.32 & & & & & \\
\hline
\end{tabular}

Table.3 Grain yield and Water productivity of puddle irrigated rice under different methods of sowing (mean data of two seasons)

\begin{tabular}{|c|c|c|c|c|c|c|c|}
\hline \multicolumn{4}{|c|}{ Treatment } & \multicolumn{4}{|c|}{ Method of sowing } \\
\hline \multicolumn{4}{|c|}{ Direct Seeded Rice } & \multicolumn{4}{|c|}{ Transplanted Rice } \\
\hline $\begin{array}{l}\text { Date of } \\
\text { Sowing }\end{array}$ & $\begin{array}{l}\text { Grain } \\
\text { Yield } \\
\text { (q ha } \\
{ }^{1} \text { ) }\end{array}$ & $\begin{array}{l}\text { Irrigation } \\
\text { water } \\
\text { applied } \\
(\mathrm{cm})\end{array}$ & $\begin{array}{l}\text { Water } \\
\text { productivity } \\
\left(\mathrm{g} \mathrm{kg} \mathrm{grain}^{-1} \mathrm{~m}^{-}\right. \\
3 \text { ) }\end{array}$ & $\begin{array}{l}\text { Date of } \\
\text { transplanting }\end{array}$ & $\begin{array}{l}\text { Grain } \\
\text { Yield } \\
\text { (q } \text { ha }^{-} \\
{ }^{1} \text { ) }\end{array}$ & $\begin{array}{l}\text { Irrigation } \\
\text { water } \\
\text { applied } \\
(\mathrm{cm})\end{array}$ & $\begin{array}{l}\text { Water } \\
\text { productivity } \\
\left(\text { g kg grain }^{-1} \mathrm{~m}\right. \\
3 \text { ) }\end{array}$ \\
\hline $1^{\text {st }}$ June & 49.9 & 108 & 0.46 & $25^{\text {th }}$ June & 47.9 & 132 & 0.36 \\
\hline $\begin{array}{l}10^{\text {th }} \\
\text { June }\end{array}$ & 51.3 & 114 & 0.45 & $5^{\text {th }}$ July & 46.4 & 120 & 0.39 \\
\hline $\begin{array}{l}20^{\text {th }} \\
\text { June }\end{array}$ & 43.6 & 108 & 0.40 & $10^{\text {th }}$ July & 33.8 & 118 & 0.29 \\
\hline Mean & 48.3 & & & Mean & 43.8 & & \\
\hline
\end{tabular}


Table.4 Yield, water input and water productivity in transplanted and wet seeded rice

\begin{tabular}{|c|c|c|c|c|c|c|}
\hline \multirow[t]{2}{*}{ Treatment } & \multicolumn{3}{|c|}{ Transplanted } & \multicolumn{3}{|c|}{ Wet Seeded } \\
\hline & $\begin{array}{l}\text { Yield } \\
\left(\mathrm{kg} \mathrm{ha}^{-1}\right)\end{array}$ & $\begin{array}{l}\text { Water } \\
\text { input } \\
(\mathrm{mm})\end{array}$ & $\begin{array}{l}\text { Water } \\
\text { productivity } \\
\left(\mathrm{g} \mathrm{kg}_{\text {grain }}^{-}\right. \\
\left.\mathrm{m}^{-3}\right)\end{array}$ & $\begin{array}{l}\text { Yield } \\
\left(\mathrm{kg} \mathrm{ha}^{-1}\right)\end{array}$ & $\begin{array}{l}\text { Water } \\
\text { input } \\
(\mathrm{mm})\end{array}$ & $\begin{array}{l}\text { Water } \\
\text { productivity } \\
\left(\mathrm{g} \mathrm{kg}^{\mathrm{grain}}{ }^{-}\right. \\
\left.\mathrm{l}^{-3}\right)\end{array}$ \\
\hline $1 *$ & $6987 \mathrm{a}$ & $728 \mathrm{a}$ & 0.96 & $8173 a$ & $577 \mathrm{a}$ & 1.42 \\
\hline $2 *$ & $6200 \mathrm{a}$ & $491 b$ & 1.26 & $8441 \mathrm{a}$ & $456 a$ & 1.85 \\
\hline $3 *$ & $6626 a$ & $477 b$ & 1.39 & $7410 \mathrm{a}$ & $391 \mathrm{a}$ & 1.90 \\
\hline $4 *$ & $6135 a$ & $600 \mathrm{ab}$ & 1.02 & $8199 a$ & $456 a$ & 1.80 \\
\hline Mean & 6487 & 574 & 1.16 & 8056 & 470 & 1.74 \\
\hline \multicolumn{7}{|c|}{ Source: Tabbal et al., 2002} \\
\hline \multicolumn{7}{|c|}{$\begin{array}{l}\text { * 1: Continuous standing water }(2-5 \mathrm{~cm} \text { depth); } 2 \text { : Standing water until panicle initiation, saturated soil thereafter; } 3 \text { : } \\
\text { Continuous saturated soil; } 4 \text { : Application of irrigation water (up to } 5-7 \mathrm{~cm} \text { depth) one day after standing water has } \\
\text { disappeared } \\
\text { *Rainfall during the experiment was } 20 \mathrm{~mm}\end{array}$} \\
\hline
\end{tabular}

\section{Physical conditions}

Sharma et al., (1995) observed that direct seeding of rice helped to maintain good physical conditions of soil which proved advantageous in attaining desired tilth and timely sowing of the succeeding crop. Otani et al., (1996) found non-puddling was superior to puddling in water retentivity, drainage, tillage facility and soil bearing capacity.

\section{Quality parameters}

Nagoshi et al., (1995) compared three methods of cultivation of rice i.e., transplanting of young seedlings, nurseling seedlings and direct sowing in flooded fields and reported that protein content of milled rice was minimum and taste index was maximum in direct sown rice. Won et al., (1996) reported that transplanting, drilling and hill sowing gave significantly similar milled rice yields. But Sorour et al., (1998) reported that mechanical transplanting gave higher hulling, milling and head rice recovery percentages than traditional transplanting, broadcasting and mechanical drilling. Singh (2002) compared furrow planting and transplanting in flat puddled field (recommended) and found non-significant differences in brown rice, milled rice and head rice recovery and also observed that brown rice, milled rice and head rice recovery of transplanted rice in flat puddle field or in furrows was significantly more over the direct seeded rice due to more thousand grain weight of transplanted rice. Gill and Walia (2014) reported that quality characters of basmati rice like brown, milled and head rice recovery were statistically at par among machine transplanting, direct seeding and conventional transplanting methods of establishment of basmati rice.

In conclusion,

i. The use of FYM in conjunction with inorganic fertilizers help to increase the yield attributes as well as yield of crop.

ii. Available nutrients, porosity, organic carbon, cation exchange capacity (CEC), aggregation of soil improved with application of FYM and bulk density reduced.

iii. Application of chemical fertilizers in conjunction with FYM will improve the quality of agricultural produce without 
losing quantity as compared to chemical fertilizers alone.

iv. Direct seeded rice with brown manuring Sesbania gave comparable yield to conventional transplanting of rice.

v. Yield of rice increased with increase in dose of nitrogen upto a certain level, after that increase in nitrogen dose was uneconomical.

vi. Direct seeded rice gave higher water-use efficiency, maintained good physical conditions and provided chance for timely sowing of succeeding wheat crop.

vii. Similar quality parameters of rice (hulled, milled and head rice recovery) were recorded with different establishment methods.

\section{References}

Anonymous. 2014. Area and production of rice in India. http://www.indiastat.com.

Aslam, M., Hussain, S., Ramzan, M., Akhtar, M. 2008. Effect of different stand establishment techniques on rice yield and its attributes. J. Animal and Plant Sci., 18: 79-82.

Azad, B.S. and Lehria, S.K. 2001. Yield maximization of rice through integrated nutrient management under irrigated conditions. Annals Agri. Res., 22: 471475.

Bajpai, R.K., Upadhyay, S.K. and Tripathi, R.S. 2002. Productivity and economics of rice-wheat cropping system under integrated nutrient supply system. Indian J. Agron., 47: 20-25.

Balasubramanian, V. and Hill, J. 2002. Direct wet seeding of rice in Asia: Emerging issues and strategic research needs for the 21st century, paper presented at the Annual Workshop of the Directorate of rice Research, Hyderabad, India, 7th April, 2002.

Bhagat, R.M., Verma, T.S. 1991. Impact of rice straw management on soil physical properties and wheat yield. Soil Sci., 152: 108-115.

Bharambe, A.P. and Tomar, A. 2004. Direct and residual effect of FYM and inorganic nutrients on rice-wheat cropping system in vertisol. PKV Res. J., 28: 47-52.

Brar, B.S., Dhillon, N.S. and Chand, M. 1995. Effect of FYM application on grain yield, uptake and availability of nutrients in rice-wheat system. Indian $J$. Agri. Sci., 65: 350-353.

Budhar, M.N. and Tamilselvan, N. 2002. Effect of stand establishment techniques on yield and economics of lowland irrigated rice (Oryza sativa L.). Indian J. Agron., 47: 57-60.

Budhar, M.N., Palaniappan, S.P and Rangaswamy, A. 1990. Performance of CR666-18 rice under transplanted and direct seeded conditions. Oryza, 27: 208-209.

Chitale, S., Urkurkar, J.S., Upadhyay, S.K., Bajpai, R.K and Tiwari, A. 2004. Management of organic manures in association with chemical fertilizers in rice-wheat cropping systems in Chhattisgarh. Proc. National Symp on Resource Conservation and Agricultural Productivity, Nov. 22-25, 2004, Ludhiana, Punjab.

Dhiman, S.D., Nandal, D.P and Om, H. 1999. Performance of scented and non-scented rice (Oryza sativa L.) genotypes under direct seeding and transplanted conditions. Indian J. Agron., 44: 335339.

Dixit, G. and Gupta, B.R. 2000. Effect of FYM, chemical and biofertilizers on yield and quality of rice and soil properties. J. Indian Society and Soil Sci., 48: 773-780.

Gill, J.S. and Walia, S.S. 2014. Effect of establishment methods and nitrogen levels on basmati rice (Oryza sativa L.). Indian J. Agron., 58: 506-511. 
Gill, J.S. and Walia, S.S. 2014. Quality and grain yield of basmati rice as influenced by different establishment methods and nitrogen levels. Asian J. Soil Sci., 8: 311-318.

Gill, M.S., Kumar, A. and Kumar. P. 2006a. Growth and yield of rice (Oryza sativa L.) cultivars under various methods and times of sowing. Indian J. Agron., 51: 23-27.

Gill, M.S., Kumar, P and Kumar, A. $2006 \mathrm{~b}$. Growth and yield of direct-seeded rice (Oryza sativa L.) as influenced by seedling techniques and seed rate under irrigated conditions. Indian J. Agron., 51: 283-287.

Goel, A.C and Verma, K.S. 2000. Comparative study of direct seeding method in Punjab. Intensive Agric., 41: 22-23.

Gupta, R K., Singh, Y., Singh, V and Singh, B. 2006. Integrated nutrient management for improving soil and crop productivity in rice-wheat crop rotation in northwestern India. Indian Farming, 10-14.

Hukkeri, S.B and Sharma, A.K. 1980. Water use efficiency of transplanted and direct sown rice under different water management practices. Indian J. Agri. Sci., 50: 240-243.

Jaiswal, V.P and Singh, G. 2001. Effect of planting methods, source and levels of nitrogen on the growth and yield of rice (Oryza sativa L.) and on succeeding wheat (Triticum aestivum L.). Indian J. Agron., 46: 5-11.

Khan, U., Mishra, B., Pachauri, P and Kumar, Y. 2006. Effect of integrated nitrogen management on yield and nitrogen nutrition of irrigated rice (Oryza sativa L.). Indian J. Agri. Sci., 76: 176-180.

Kumar, M.S. and Mukherjee, P.K. 2008. Integrated weed management in dry direct-seeded rainy season rice (Oryza sativa L.). Indian J. Agron., 53: 107-
111.

Kumar, M., Singh, R.P and Rana, N.S. 2003. Effect of organic and inorganic sources of nutrient on productivity of rice. Indian J. Agron., 48: 175-177.

Laroo, N.M., Shivay, Y.S and Kumar, D. 2007. Effect of nitrogen and sulphur fertilization yield attributes productivity and nutrient uptake of aromatic rice (Oryza sativa L.). Indian J. Agri. Sci., 77: 762-775.

Lawal, M.I and Lawal, A.B. 2002. Influence of nitrogen rate and placement method on growth and yield of rice (Oryza sativa L.) at Kadawa, Nigeria. Crop Res., 23: 403-411.

Maskina, M.S., Singh, B., Singh, Y., Baddesha, H.S and Meelu, O.P. 1988. Fertilizer requirement of rice-wheat and maize-wheat rotation on coarse-textured soils amended with FYM. Fertil. Res., 17: 153-164.

Meena, S.L., Singh, S. and Shivay, Y.S. 2003. Response of hybrid rice Oryza sativa $\mathrm{L}$. to nitrogen and potassium application in sandy clay-loam soil. Indian J. Agri. Sci., 73: 8-11.

Mishra, B.N., Kumar, D and Shivay, Y.S. 2006. Effect of organic sources on productivity, grain quality and soil health of rice (Oryza sativa L.)-wheat (Triticum aestivum L.) cropping system. Proc National Symp on Conservation Agri. and Environment. Oct. 26-28. 2006, BHU, Varanasi, p 280.

Mishra, V.K. and Sharma, R.B. 1997. Effect of fertilizers alone and in combination with manure on physical properties and productivity of entisol under rice-based cropping system. J. Indian Society of Soil Sci., 45: 84-88.

Mondal, S.S., Sarkar, S., Ghosh, A and Das, J. 2003. Response of summer rice (Oryza sativa L.) to different organic and inorganic sources of nutrients. Crop Res., 25: 219-222. 
Nagappa, N., Dnmavalli and Biradar, D P. 2002. Drum seedling of sprouted rice seed in a farmer's field: an economic analysis. Int. Rice Res. Newslett., 27: 54-55.

Nagoshi, T., Tamai, F and Motoda, Y. 1995. Effect of different cultivation methods on growth, yield and quality of rice plants. Indian J. Agri. Sci., 40: 46-56.

Narayansamy, R., Palaniappan, S. and Veerabadran, V. 1993. Effect of seeding environment on irrigation requirement and yield of kuruvai rice in double cropping lowlands in Thanjavur. Madras Agri. J., 80: 639-640.

Otani, R., Cole, C.V., Watanabe, F.S and Dean, L.A. 1996. Studies on nonpuddling rice direct seeding (part I). Physical property of soil and tillage facility. J. Soc. Agric. Mach., 58: 73-80 (Abstr).

Parasuraman, P. and Mani, A.K. 2002. Growth, yield and economics of rice (Oryza sativa L.)-finger millet (Eleusine coracana L.) crop sequence as influenced by FYM and coir pith with and without inorganic fertilizers. Indian J. Agron., 48: 12-15.

Parihar, S.S. 2004. Effect of crop establishment method, tillage, irrigation and nitrogen on production potential of rice (Oryza sativa L.)-wheat (Triticum aestivum L.) cropping system. Indian J. Agron., 49: 1-5.

Prasad, D., Singh, J.P., Singh, J.K and Bharati, V. 2003. Effect of irrigation and nitrogen on growth and yield of early rice (Oryza sativa L.). RAU J. Res., 13: 148-150.

Raju, R.A and Reddy, M.N. 2000. Sustainability of productivity in rice (Oryza sativa L.)-rice (Oryza sativa L.) sequential cropping system through integrated nutrient management in coastal ecosystem. Indian J. Agron., 45: 447-452.
Rao, K.S., Moorthy, B.T.S., Lodh, S.B and Sahoo, K. 1993.Effect of graded levels of nitrogen on yield and quality of different varieties of scented rice. Indian J. Agri. Sci., 63: 467-472.

Rao, S.A.V., Prasad, P.V.N and Venkateswarlu, B. 2006. Synergistic influence of nitrogen and zinc on grain yield and quality of rice (Oryza sativa L.). Proc National Symp on Conservation Agri. and Environment. Oct. 26-28, BHU, Varanasi. Pp. 181182.

Roul, P.K and Sarawgu, S.K. 2005. Effect of integrated nitrogen nutrition techniques on yield, $\mathrm{N}$ content, uptake and use efficiency of rice (Oryza sativa L.). Indian J. Agron., 50: 129-131.

Samra, J S. and Dhillon, S S. 2000. Production potential of rice (Oryza sativa L.)-wheat (Triticum aestivum L.) cropping system under different methods of crop establishment. Indian J. Agron., 45: 21-24.

Sanjay, M.T., Prabhakara, T.K and Nanjappa, H.V. 2006a. Enhancing productivity of rice (Oryza sativa L.) under different crop establishment methods through weed management practices. Crop Res., 31: 192-197.

Sanjay, M.T., Prabhakara, T.K., Nanjappa, H.V. 2006b. Soil test crop response approach in rice (Oryza sativa L.) under different methods of crop establishment. Crop Res., 31: 346-349.

Santhi, P.K., Ponnuswamy and Kempuchety. 1998a. A labour saving technique in direct sown and transplanted rice. Int. Rice Res. Newslett., 23: 35.

Sharma, A.R. and Mittra, B.N. 1990. In ricebased cropping system in eastern India organic manure should be combined with chemical fertilizers. Indian Farming, 40- 42.

Sharma, D.P., Sharma, S.K., Joshi, P.K., Singh, S and Singh, G. 2008. Resource 
conservation technologies in reclaimed alkali soils. Technical Bulletin 1/2008. Central Soil Salinity Res. Institute, Karnal. http://www.cssri.org.

Sharma, R.S., Thakur, C.L and Aggarwal, K K. 1995. Comparison of transplanted and direct seeded rice for productivity, profitability and physical properties of soil. Oryza, 32: 183-187.

Shrivastava, B.K and Tripathi, R.S. 1999. Effect of nitrogen levels on hybrid and high yielding varieties of rice under lowland ecology of eastern Madhya Pradesh, India. Oryza, 36: 386-388.

Singh, A.K., Amgain, L.P and Sharma, S.K. 2000a. Root characteristics, soil physical properties and yield of rice as influenced by integrated nutrient management in rice-wheat system. Indian J. Agron., 45: 592-600.

Singh, D. 2002. Evaluation of different planting techniques for yield optimization and water saving in paddy (Oryza sativa L.). M.Sc. Thesis, Punjab Agricultural University, Ludhiana, India.

Singh, G., Sharma, D.P., Singh, A.K and Malik, R.K. 2009. Evaluation of resource conservation technologies in rice-wheat cropping system. Conservation Agri. experiment at CSSRI, India. http://www.cssri.org.

Singh, G., Singh, O P. and Yadav, R A. 1990. Effect of methods of establishment and nitrogen application on yield and yield attributes of rice. Oryza, 27: 210-213.

Singh, K M., Pal, S K., Verma, V N., Thakur, R. and Singh, M K. 1997. Effect of time and methods of planting on performance of rice cultivar under medium land of Bihar plateau. Indian J. Agron., 42: 443-445.

Singh, M and Sharma, S.N. 2000. Effect of wheat residue management practices and nitrogen rates on productivity and nutrient uptake of rice (Oryza sativa
L.)-wheat (Triticum aestivum L.) cropping system. Indian J. Agri. Sci., 70: 835-839.

Singh, R P., Singh, C M and Singh, A K. 2005a. Effect of crop establishment methods, weed management and split nitrogen application on weed and yield of rice (Oryza sativa L.). Indian J. Agri. Sci., 75: 285-287.

Singh, S., Singh, S.S and Jat, M.L. 2008 b. Effect of intercropping of sesbania sown at different times on weed density and grain yield of rice. Res. experiment at CIMMYT, India. http://www.rwc.cgiar.org.

Singh, S., Singh, S.S and Jat, M.L. 2008c. Effect of brown manuring on weed density and rice yield. Res. experiment at PDCSR, Modipurum, UP, India. http://www.rwc.cgiar.org.

Singh, V.P., Singh, G., Singh, R.K., Singh, S.P., Kumar, A., Sharma, G., Singh, M K., Mortimer, $\mathrm{M}$ and Johnson, D.E. 2005b. Effect of weed management and crop establishment methods on weed dynamics and grain yield of rice (Oryza sativa L.). Indian J. Weed Sci., 37: 188192.

Singh, Y., Gupta, R.K., Singh, B. and Gupta, S. 2007. Efficient management of fertilizer nitrogen in wet direct seeded rice (Oryza sativa L.) in North West India. Indian J. Agri. Sci., 77: 561-564.

Sorour, S G R., Keredy, M S., Mosalin, M E. and Hegazy, A M. 1998. Evaluation of planting methods on two rice cultivars. Proc 7th Conference of Agricultural Development Res., Cairo, Egypt, 15-17 December, 3: 645-61.

Sujathamma, P. and Reddy, S.D. 2004. Growth, yield and nitrogen uptake of low land rice as influenced by integrated nutrient management. Indian J. Agri. Res., 38: 268-272.

Tabbal, D F., Bouman, B M., Bhuiyan, S I., Sibayan, E B. and Sattar, M A. 2002. 
On-farm strategies for reducing water input in irrigated rice; case studies in the Philippines. Agric. Water Manage., 56: 93-112.

Thabonithy, R and Murali, N.S. 1994. Water productivity of irrigated rice under transplanting, wet seeding and dry seeding. Proc International Agricultural Conference, Asian Institute of Technology, Thailand, 2: 6-9.

Tiwari, A., Nema, H.R., Tembhare, B.R and Sharma, S.K. 2000. Soil physical environment in long term fertilizer experiment on Typic Haplustorts. JNKVV Res. J., 34: 29-33.

Won, J G., Lee, W H., Choi, C D., Kim, C R. and Choi, B.S. 1996. Growth characteristics and yield of hill seeded rice in direct seeding. RDA J. Agri. Sci., 38: 49-55.

Zhang, S.Y., Zhu, X.H. 1999. Key factors affecting the yield of dry raised rice seedlings for broadcast transplanting in hilly areas of Jiangsu. Agri. Sci., 2: 1617.

\section{How to cite this article:}

Ashu Sharma, Neetu Sharma, Anil Kumar, B.C. Sharma, Lobzang Stanzen, Amit Mahajan and Sapna Bhagat. 2017. Influence of FYM, Brown Manuring and Nitrogen Levels on Direct Seeded and Transplanted Rice (Oryza sativa L.): A Review. Int.J.Curr.Microbiol.App.Sci. 6(8): 1794-1807. doi: https://doi.org/10.20546/ijcmas.2017.608.212 